\title{
WHEN BEING IN SOCIAL EXCLUSION RISK BECOMES RISKIER: SCHOOL OF SLIMNIC, VRANCEA, ROMANIA, IN PANDEMIC
}

\author{
Doina CROITORU ${ }^{1 *}$, Ana GAVRILESCU ${ }^{2}$ \\ ${ }^{1}$ National University of Physical Education and Sport, Faculty of Physical Education and Sport, Bucharest, \\ Romania \\ ${ }^{2}$ Middle School, Tamboesti, Vrancea, Romania \\ *Corresponding author: doina.croitoru@gmail.com
}

DOI: https://doi.org/10.51267/icpesk2020bp03

\begin{abstract}
For the whole world, the COVID-19 pandemic is a risk situation. All domains of activity are certainly affected by isolation and social distancing measures. Each social field is differently affected, but the Education sector is facing major challenges for teachers, students and institutional managers. In Romania, school activities have been suspended starting 12 March and there is a possibility to reopen them in September. Until then, all activity has been transferred online. In our case study, we examined a school from a disadvantaged part of the country, which is included in a predefined project called "Sustainable social and educational integration through sports activities". The project takes place at the National University of Physical Education and Sport, Bucharest, Romania, in partnership with the Norwegian School of Sport Sciences. The objective of the project is to facilitate the educational and social integration of 2600 children at risk of social exclusion, selected from the 8 development regions of the country, through integrated activities based on sport. During school closure in the spring of 2020 (due to the COVID-19 pandemic), the situation for School no. 67, grades 5-8 (a sample that is in the project, mainly Roma population), is as follows: only 3 students have laptops, 2 students have personal computers, and 30 students have smartphones. Out of all 67, 35 communicate online, but 32 do not. The communication methods used for students with no online access include worksheets sent by regular mail, messages sent to keypad phones and talking using the landline.
\end{abstract}

Keywords: social exclusion risk, distance education, COVID-19 pandemic, Roma children.

\section{Introduction}

In our case study, we examined a school from a disadvantaged part of the country, which is included in a predefined project called "Sustainable social and educational integration through sports activities". The project takes place at the National University of Physical Education and Sport (UNEFS) in partnership with the Norwegian School of Sport Sciences. The objective of the project is to facilitate the educational and social integration of 2600 children at risk of social exclusion, selected from 8 development regions of the country, through integrated activities based on sport.

The project started from the idea that integrating sports activities among extracurricular ones would encourage interaction between students. Participating in extracurricular activities provides socialising opportunities for students who are marginalised for different reasons (social reasons, suboptimal academic results, shyness), helps to raise self-esteem and improves the attitude towards school (McNeal, 1995).

Regarding social exclusion and poverty in Romania, the key aspects are synthesised in the "National anti-poverty and promotion of social inclusion plan" (by the Romanian Government, published in the Official Gazette no. 662 on the $6^{\text {th }}$ of September 2002): 
- There are children who do not have identification documents, who are not included in the educational system, children with disabilities from broken and poor families;

- Because of school dropout, some children do not fulfil 8 grades;

- Rural-urban disparities (teachers with different levels of training, didactic materials, distances to and from schools);

- The existence of school risk groups - children with disabilities, Roma population, broken and poor families, isolated rural areas.

Children, as members of a family, may suffer because their parents are excluded, and the obstacles that this situation brings obstructs their own development. This will be the origin of the exclusion that they will experiment themselves later in life (Bynner \& Parsons, 2002).

In Romania, this process has a series of causes such as: poor acquisition of fundamental reading, writing and arithmetic skills; poor school results; early school dropout with no job qualification; increased difficulty in entering the labour market, including areas of unskilled labour; occasional work and unemployment; early pregnancy; problems with the police; alcoholism; poor physical health and, more importantly, mental health.

For the whole world, the 2020 pandemic is certainly a risk situation: "COVID-19 puts societies to the test" (The Lancet Public Health, 2020).

We consider that isolation measures and new social distancing rules irrefutably affect all domains of activity. Each social field is affected, but the Education sector is facing major difficulties for teachers, students and institutional managers.

For us, until this spring, the concept of distance education was mainly a subject of theoretical debates and plans for a distant future. When the COVID-19 pandemic hit our country, we were totally unprepared - teachers, students and managers all the same. In Romania, one of the measures to reduce virus transmission was to suspend school activities starting 12 March (when 18 new cases were confirmed, bringing the total to 47). The current perspective is to reopen schools in September. Until then, the whole activity is transferred online. Examining recent analyses regarding the virus reproduction rate and school closure as an isolation measure (Remuzzi \& Remuzzi, 2020; Liu et al., 2020; Viner et al., 2020), this date might be changed.

Alarms are already appearing in many scientific papers addressing different scientific fields, as summarised by Haleem et al. (2020).

We think that, if home confinement is beneficial from the perspective of children's physical safety, its effects will last a long time due to future health implications. In addition to extending school time, the COVID-19 pandemic exacerbates all risk factors for weight gain. The coronavirus crisis is already affecting children's lives (Ramchandani, 2020). School closure, the disappearance of outdoor activities, new dietary and sleeping habits (as parents do not impose many rules now) are likely to disrupt children's usual lifestyles. For many of them, mainly those living in urban agglomeration in small apartments, various neuropsychiatric manifestations may appear, as well as impatience, annoyance, distress.

The pandemic has already impacted us. There are studies on its emotional impact (Montemurro, 2020), psychological impact (Cao et al., 2020) and mental health problems (Gao et al., 2020). There will be repercussions on the workforce (Bayham \& Fenichel, 2020), global supply chains (Ivanov, 2020), poverty (Buheji et al., 2020). Recent studies tackle less obvious and impactful effects such as the impact of COVID-19 on the media system (Casero-Ripollés, 2020) or on sporting mass gatherings in performance sports (Parnell et al., 2020). 


\section{Results}

In Romania, according to the activities of national economy, $22.3 \%$ of employed people work in agriculture. The rest are in non-agricultural sectors, $24.8 \%$ in manufacturing, $18.4 \%$ in trade and $10.0 \%$ in construction. When looking at Romania on a map, Vrancea County can be identified in the south-east region, next to the Eastern Carpathian Mountains, and represents a connection point between three large historical provinces: Moldova, Wallachia and Transylvania. The geography of Vrancea County can be likened to the appearance of huge steps that descend from West to East, the first step being the Vrancea Mountains, which range from a height of $960 \mathrm{~m}$ to $1785 \mathrm{~m}$. The next step are the hills, with altitudes between $350 \mathrm{~m}$ and $1000 \mathrm{~m}$. The third and final step is the plain, a vast platform that reaches the Siret, Trotus and Ramnic waters. The most active seismic part of Romania is located here, in Vrancea County, with the epicentre in Vrancioaia town. According to statistics, there is an average of two earthquakes per day in this area, most of them imperceptible to human senses. Forests occupy approximately $38 \%$ of the county area, and vineyards occupy $11 \%$, representing about $6 \%$ of the total vineyard areas in Romania. Vrancea County has the largest viticulture area in our country. Vrancea forests support the wood and furniture industry, and rich crops of grapes result in obtaining a wide range of drinks. The geographical configuration and rich pastures favour animal husbandry, especially sheep and cattle, thus providing support for the food industry, particularly the meat and milk processing industry.

Tamboesti Middle School in located in the centre of Tamboesti town, Vrancea County. Tamboesti town includes the following villages: Padureni, Pietroasa, Slimnic, Tamboesti (the residence) and Trestieni, all with a total population of 2887 inhabitants. The town does not have a majority ethnic group, its inhabitants being $48.56 \%$ Romanian and $48.08 \%$ Roma. For the remaining $3.36 \%$ of the population, ethnicity is unknown.

Tamboesti Middle School defines itself as a school focused on promoting democratic values and principles by involving the community in school life and expanding school services for the community. The educational climate of the school is based on cooperation, encouraging individual initiative and didactic innovation meant to support the individual development of each student and equal opportunities through education.

This education unit is a legal entity and has several subordinate structures: two kindergartens with normal schedules, a school with grades from 1 to 4 , and a school with grades from 1 to 8 - Slimnic Middle School.

According to Romanian law, the school in Slimnic village is too small to be an independent unit, therefore it is administratively under the legal jurisdiction of the nearest larger school unit, Tamboesti School.

The Slimnic Middle School building is small, it only has 5 classrooms, which is why students are split into two series. Besides the 5 classrooms, there is also a space for the teachers' room, a space for the library, a space for depositing didactic materials and a play area where physical education lessons are also held. The school has Internet access and IT facilities obtained through another project.

At Slimnic Middle School, the teaching process occurs in two series: the first in the morning - 135 primary school students (grades 1 to 4 ), and the second in the afternoon - 68 middle school students (grades 5 to 8). 
An overwhelming proportion of students come from a disadvantaged background with limited financial possibilities, as their families' main source of income is field work, social assistance and state child-raising allowance. $64 \%$ of students belong to the Roma ethnic group.

The reduction of family income and exclusion generated by poverty and ethnicity lead to student demotivation, and parents' exodus abroad to work negatively influence children's development.

The school has a high percentage of dropout rates and a very small percentage of children's access to a higher form of education (ISCED 3). As can be seen from the situation of the school included in our project (Table 1), less than half of those who completed the $8^{\text {th }}$ grade in 2019 continued their studies (7 out of 16).

Table 1. Slimnic Middle School (structure of Tamboesti Middle School, Vrancea County) Current situation

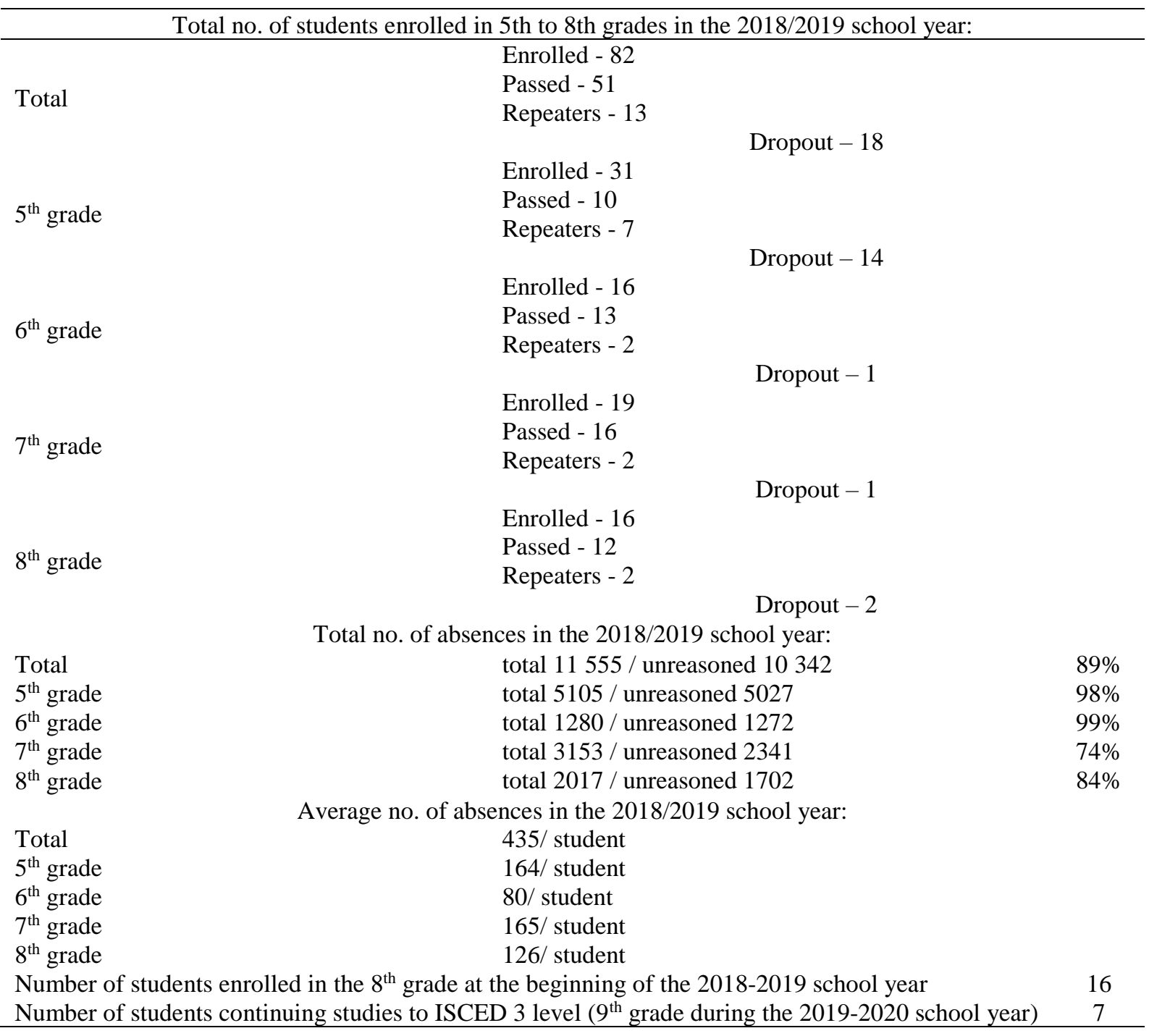

Slimnic School started the 2019-2020 school year with a total number of 68 students. From the beginning of the school year (September 2019) to the present (April 2020), one student dropped out of school and left the village - his relatives said he was "abroad to work". 
When Romania entered the state of emergency because of the COVID-19 pandemic, schools were closed and all learning activities were transferred online. Teachers, although completely unprepared for this, were asked to work with children in a "virtual environment". The term distance education is used to describe "courses that are delivered to students who are not present in the same room", while "online classes are courses that are delivered completely on the Internet" (Tallent-Runnels et al., 2006, p. 94). None of the Slimnic School teachers had completed any online teaching course and none of them qualified as an e-tutor.

Analysing the numerical situation of the 67 middle school students in grades 5-8 (sample/ target group included in our project), we have come to the conclusion that 3 students have laptops, 2 have desktop computers, and 30 have smartphones. Basically, out of the 67 students in grades 5-8, 35 have access to online communication, but 32 do not (Figures 1 and 2).

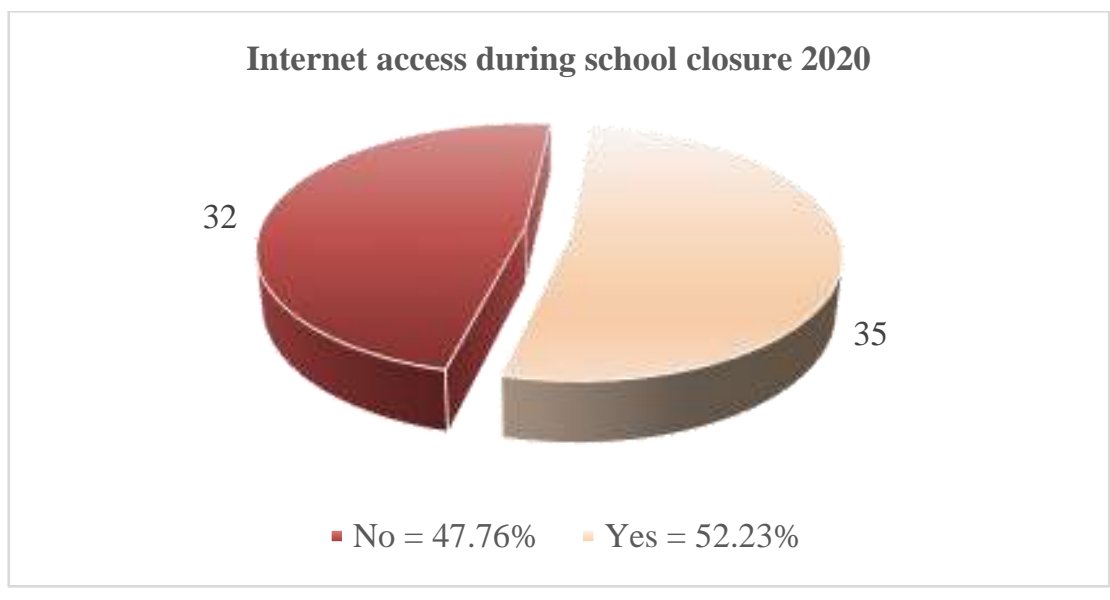

Figure 1. Internet access for students during school closure 2020, Slimnic School, Vrancea County, April 2020 (a) 32 students with no Internet access (47.76\%); (b) 35 students with Internet access $(52.23 \%)$

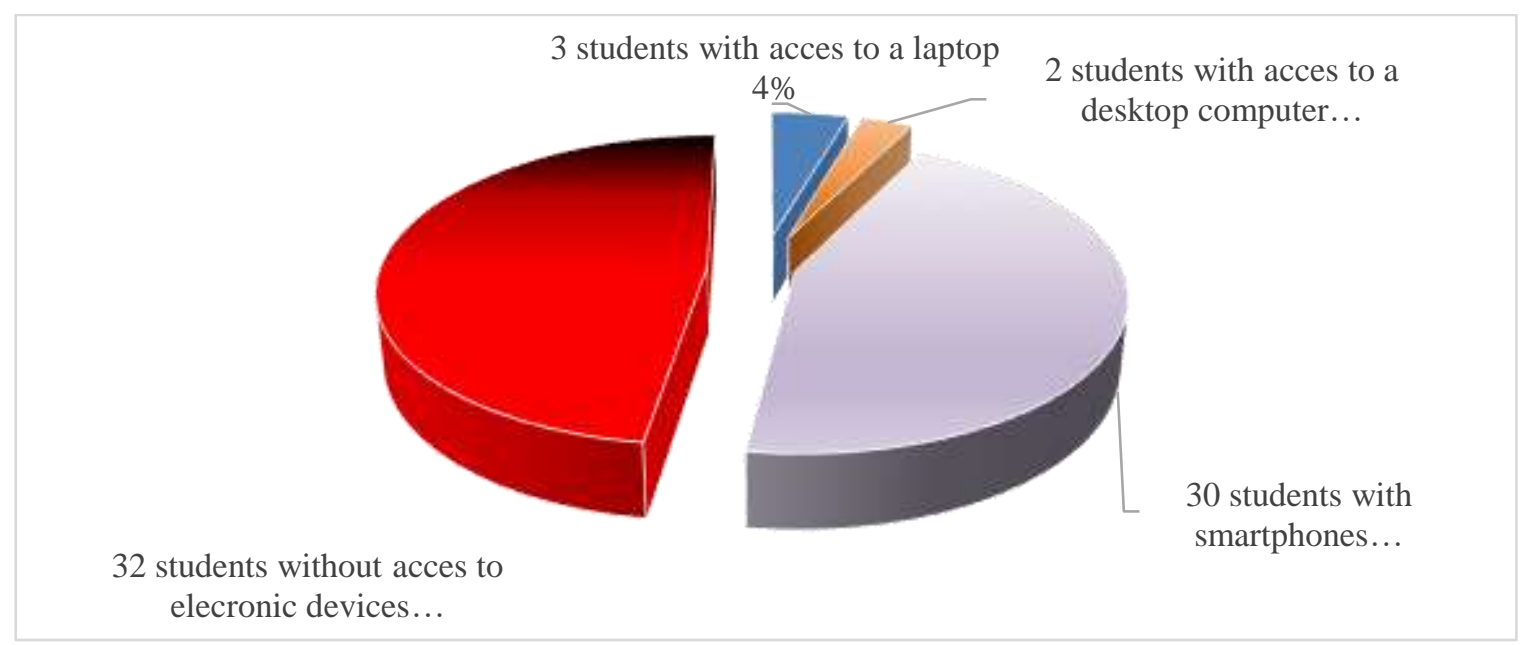

Figure 2. Type of Internet access by desktop computer, notebook or smartphone during school closure 2020, Slimnic School, Vrancea County, April 2020 (a) students without access to electronic devices, (b) students with access to laptops, (c) students with access to desktop computers, (d) students with access to smartphones 
Many students who do not have online access are in the $8^{\text {th }}$ grade ( 7 out of $18-38.8 \%$ ), the same ones who are supposed to take an exam in June, which will decide the continuation of their studies at high school or vocational school.

The fewest students with whom teachers can communicate are in the $5^{\text {th }}$ grade: out of 25 students, only 7 (28\%) have access to a means of communication via the Internet. 18 students (72\%) do not communicate online. (Table 2 and Figure 3)

Table 2. Students communicating online (Slimnic School, April 2020)

\begin{tabular}{|c|c|c|c|c|}
\hline & & Total students & YES & NO \\
\hline 5th grade & & 25 & $7(28 \%)$ & $18(72 \%)$ \\
\hline 6th grade & & 11 & $9(81.8 \%)$ & $2(18.1 \%)$ \\
\hline 7th grade & & 13 & $8(61.5 \%)$ & $5(38.4 \%)$ \\
\hline 8th grade & & 18 & $11(61.1 \%)$ & $7(38.8 \%)$ \\
\hline & Total/school & 67 & 35 & 32 \\
\hline
\end{tabular}

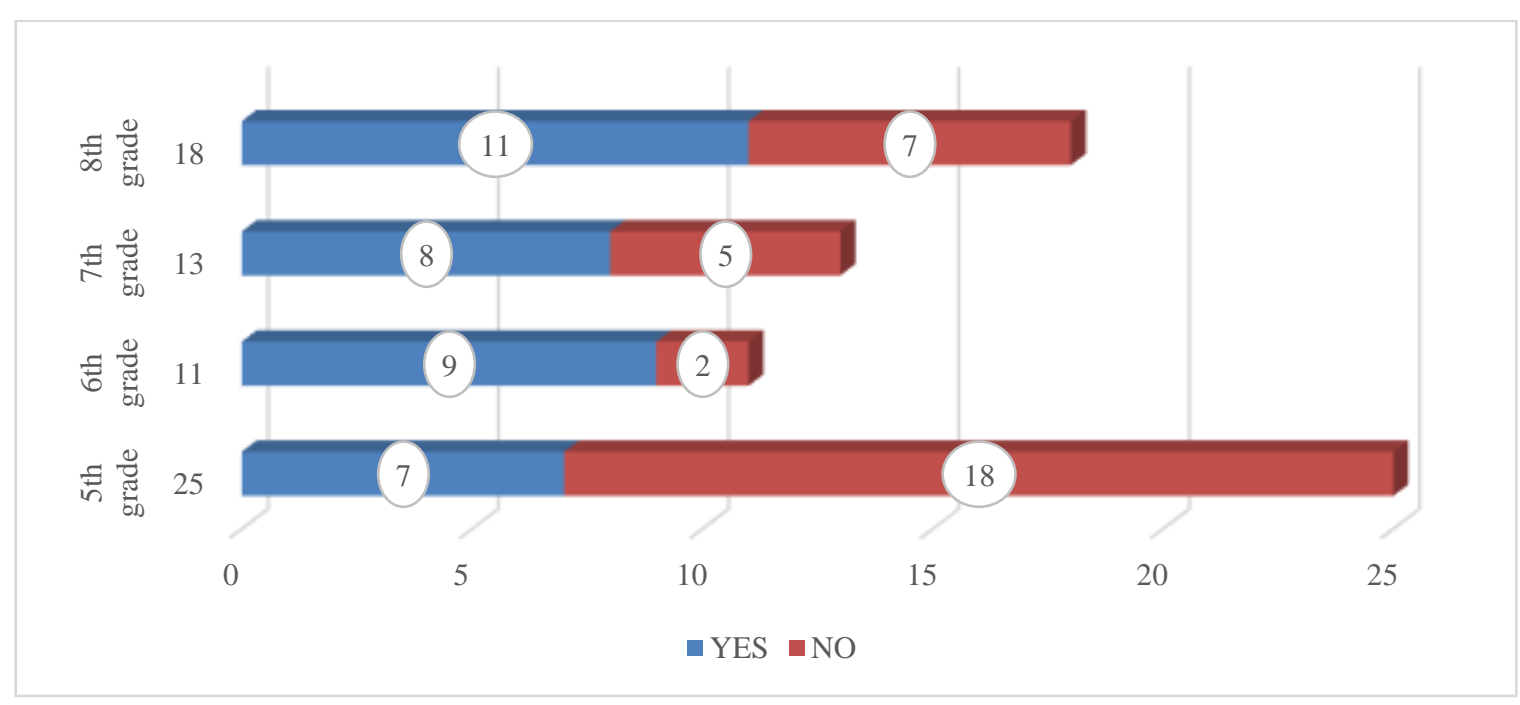

Figure 3. Student participation in online lessons by grade, Slimnic School, Vrancea County, April 2020 (a) $5^{\text {th }}$ grade, (b) $6^{\text {th }}$ grade, (c) $7^{\text {th }}$ grade, (d) $8^{\text {th }}$ grade

Communication methods presently used at Slimnic School for students who do not have online access include: worksheets sent by regular mail, messages sent to keypad phones and talking using the landline. For the lessons to be sent to students by regular mail, the teachers go to the school, print the materials, multiply them and put them in envelopes. These are then taken at the village post office from where the mail man takes them to the students' homes. This process takes 1-2 days.

Schrum and Hong (2001, cited in Steele, 2012) completed a survey with 70 institutions and have found eight dimensions that affect student success in distance education; these included "access to tools, technology experience, study habits, goals, learning preferences, purposes, lifestyles, and personal traits" (p. 39). We cannot consider any of the aforementioned dimensions as factors for ensuring success in Slimnic School while classes are suspended.

For online education, Muilenburg and Berge (2005) identified eight factors: "(1) administrative issues, (2) social interaction, (3) academic skills, (4) technical skills, (5) learner 
motivation, (6) time and support for studies, (7) cost and access to the Internet, and (8) technical problems" (p. 29). Other independent variables that significantly affected students included: "gender, age, ethnicity, type of learning institution, self-rating of online learning skills, effectiveness of learning online, online learning enjoyment, prejudicial treatment in traditional classes, and the number of online courses completed" (Muilenburg \& Berge, 2005, p. 29). For students at risk of social exclusion from Slimnic School, we can state that point (7), "cost and access to the Internet", is the major activity-limiting factor.

A classic and highly cited survey (Volery \& Lord, 2000) identified three critical success factors: "technology, the instructor and the previous use of the technology from a student's perspective" (p. 216). In our case, the previous use of the technology in learning is almost inexistent for both teachers and students from Slimnic.

More than the lack of education, school closure exacerbates food insecurity. The number of children facing food insecurity is substantial. According to Eurostat, $6 \%$ of households with children in the European Union cannot afford a meal with meat, fish, or a vegetarian equivalent every second day. In our research sample, the percentage is much higher, and this is one of the reasons for inclusion in our project. For many students living in Slimnic, school is not only a place for learning but also for eating. Much of the project funds lunch for all students included in the target group. A previous research (Van Lancker \& Parolin, 2020) shows that "school lunch is associated with improvements in academic performance, whereas food insecurity (including irregular or unhealthy diets) is associated with low educational attainment and substantial risks to the physical health and mental wellbeing of children" (p. 243).

From an institutional perspective, distance education is a cost-intensive business (Hall, 1995). Entry into and ongoing costs of distance education are substantial. Institutions must make capital investments in computers, equipment, central servers and networks, technical assistance services, and continual software upgrades. These costs alone can be barriers for school institutions wishing to engage in distance learning. (Zirkle, 2001)

We can add scheduling, instructional concerns, technical assistance and, for students in our target group, lack of experience and training, motivation, feedback and teacher contact, as well as alienation and isolation.

\section{Conclusion}

From the perspective of "learned lessons" and inspired by Salmon's stages (2003, cited in Mayes \& De Freitas, 2004), during this pandemic period (March-May 2020), we will say that at Slimnic School, Vrancea County:

1. Internet access was poor - although we have good Internet penetration in our country (73.8\%, according to Internet World Stats), access was only $52 \%$ for the group of students. Teachers used their own home connections and equipment.

2. Motivation - teachers have tried... but it is hard to motivate a remote group already demotivated by the social environment. Most students are demotivated and at risk of social exclusion due to poverty or belonging to the Roma ethnic group.

3. Teachers and half of the students tried to socialise at a high level - online and by other means, but limitations of the current technical support were almost insurmountable; it is impossible to socialise through lessons sent by regular mail on printed papers. 
4. Regarding information exchange - it was vastly different from teacher to teacher and for each teacher and students. We did not really share, but as an excuse (mais "qui s'excuse s'accuse"), we learn to swim by jumping into deep water.

5. Knowledge acquired - we have realised that the level of autonomy is dangerous, most students leaving the task fulfilment to the last minute. Because of this, the incubation of learning did not exist and, as a result, integration and synthesis of the newly acquired information was not properly done. Facilitating tasks and supporting the use of learning materials is a new land where we, the teachers, are newly arrived with bare hands.

6. We can find pedagogical reasoning to diminish teacher intervention during the module - by forcing autonomy and insight, but we consider this approach to be very abrupt for an untrained group.

Starting from Mason's ideas (2003), we can say that:

1. Teachers proposed to do structured discussions, and students responded with both discordant ideas and scholarly answers learned from the lessons;

2. Collaborative activities? We need a lot of training, mainly because our whole educational system is based on individual tasks and individual evaluation;

3. Online evaluation provides a diversity of means: total time, quality of intervention, collaborative work. Teachers did not oblige students to memorise information, but they tended to reproduce it.

4. The materials were mostly flexible as support (in written form, videos, summaries) but not as flexible as they could be if teachers had been trained in advance.

From a pedagogical point of view: there was not enough time to fathom the knowledge we, at least, need a longer incubation time. The materials were accessible and the individualisation of learning possible. The students' intuition was also appealed due to this. One cannot induce conscientious and active participation by one side only and it is the student's rough work to really try do this too.

We have stated the importance of real-time communication because it is the only one used in learning until now, and we are not used to blending the two types of interaction - synchronous and asynchronous. For both sides, teachers and students, chatting is just an exotic type of task during synchronous courses and for many of us, teachers and especially students, to log-on at a certain hour was... mission impossible.

The problem of online time inventory is different from traditional learning time, so it is necessary for the student to develop new asynchronous communication skills. This involves skills regarding time management adequate to online learning. We consider that, in asynchronous communication, the difficulty arises from the complexity of messages and the diversity of topics. If we are dealing with a large group, these tasks will be impossible - just like trying to dialogue with the whole audience during a traditional course.

The asynchrony of written letters leads to a gap between asking and answering, which can be used by the student to reflect and prepare a good answer. As a positive result of asynchronous communication, we underline that it can produce elaborate answers that are tangible (written) and usable as a starting point for next topics and a course delivery repository.

On the one side, the ability to use distance education creates the ability to interact online and removes some of the boundaries; on the other side, it induces a specific type on interaction 
- elliptical, distilled, sometimes superficial. A good teacher should facilitate the grasp and usage of certain knowledge and find meaning, even more than delivering the content.

In real-time synchronous online classes, only one person can "speak" at a given time, just as is the case in a traditional classroom. For younger students, it is a difficult rule to respect. In the asynchronous virtual communication, everyone can (and should) jump into a discussion whenever they have something to say. Discussions should be flowing and favourable to participation, and lack of synchronicity provides the desirable flexibility. However, in this period, almost half of Slimnic School students were missing classes due to lack of access to online communication because of poverty.

Between 27 and 30 April 2020, the IRES (Romanian Institute for Evaluation and Strategy, 2020) conducted a study to find out how Romanian children had access to online education and related infrastructure. The study has shown that $32 \%$ of all children enrolled in pre-university education in Romania do not have individual access to a dedicated functional device (e.g. laptop, tablet, desktop computer) for online school.

At Slimnic School, during the COVID-19 pandemic that induced the suspension of classes, $4 \%$ of children had access to laptops and $3 \%$ to desktop computers. Adding smartphone access to the list, total access reached $52 \%$. For the remaining $48 \%$, the risk of exclusion became significantly higher.

\section{References}

Bayham, J., \& Fenichel, E. P. (2020). Impact of school closures for COVID-19 on the US health-care workforce and net mortality: A modelling study. The Lancet Public Health, 5(5), E271-E278. https://doi.org/10.1016/S2468-2667(20)30082-7

Buheji, M., da Costa Cunha, K., Beka, G., Mavrić, B., de Souza, Y. L. D. C., da Costa Silva, S. S., Hanafi, M., \& Yein, T. C. (2020). The extent of COVID-19 pandemic socio-economic impact on global poverty. A global integrative multidisciplinary review. American Journal of Economics, 10(4), 213-224. doi: 10.5923/j.economics.20201004.02

Bynner, J., \& Parsons, S. (2002). Social exclusion and the transition from school to work: The case of young people not in education, employment, or training (NEET). Journal of Vocational Behavior, 60(2), 289-309. https://doi.org/10.1006/jvbe.2001.1868

Cao, W., Fang, Z., Hou, G., Han, M., Xu, X., Dong, J., \& Zheng, J. (2020). The psychological impact of the COVID-19 epidemic on college students in China. Psychiatry Research, 287, 112934. https://doi.org/10.1016/j.psychres.2020.112934

Casero-Ripollés, A. (2020). Impact of COVID-19 on the media system. Communicative and democratic consequences of news consumption during the outbreak. El Profesional de la Información, 29(2): e290223. https://doi.org/10.3145/epi.2020.mar.23

Gao, J., Zheng, P., Jia, Y., Chen, H., Mao, Y., Chen, S., Wang, Y., Fu, H., \& Dai, J. (2020). Mental health problems and social media exposure during COVID-19 outbreak. PLoS One, 15(4): e0231924. https://doi.org/10.1371/journal.pone.0231924

Haleem, A., Javaid, M., Vaishya, R., \& Deshmukh, S. G. (2020). Areas of academic research with the impact of COVID-19. The American Journal of Emergency Medicine, 38(7), 15241526. https://doi.org/10.1016/j.ajem.2020.04.022

Hall, J. W. (1995). The revolution in electronic technology and the modern university: The convergence of means. Educom Review, 30(4), 42-45. https://www.educause.edu/apps/er/review/reviewArticles/30442.html

Internet World Stats. Usage and population statistics. (2020). Internet in Europe stats. 
https://www.internetworldstats.com/stats4.htm\#europe

IRES. (2020). Accesul copiilor școlari din România la educație online [Access of Romanian schoolchildren to online education]. https://ires.ro/articol/394/accesul-copiilor--colari-dinromania-la-educa\%C8\%9Bie-online--

Ivanov, D. (2020). Predicting the impacts of epidemic outbreaks on global supply chains: A simulation-based analysis on the coronavirus outbreak (COVID-19/SARS-CoV-2) case. Transportation Research Part E: Logistics and Transportation Review, 136, 101922. https://doi.org/10.1016/j.tre.2020.101922

Liu, Y., Gayle, A. A., Wilder-Smith, A., \& Rocklöv, J. (2020). The reproductive number of COVID-19 is higher compared to SARS coronavirus. Journal of Travel Medicine, 27(2), taaa021. https://doi.org/10.1093/jtm/taaa021

Mason, R. (2003). Models and methodologies in distance education. Discursos: Perspectivas em educação, 1, 91-101. https://repositorioaberto.uab.pt/bitstream/10400.2/151/1/RevistaDiscursos91-101.pdf

Mayes, T., \& De Freitas, S. (2004). JISC e-learning models desk study review of e-learning theories, frameworks and models. Stage 2: Review of e-learning theories, frameworks and models. https://researchrepository.murdoch.edu.au/id/eprint/32662/1/review-of-e-learningtheories.pdf

McNeal, R. (1995). Extracurricular activities and high school dropouts. Sociology of Education, 68(1), 62-81. https://doi.org/10.2307/2112764

Montemurro, N. (2020). The emotional impact of COVID-19: From medical staff to common people. Brain, Behavior, and Immunity, 87, 23-24. https://doi.org/10.1016/j.bbi.2020.03.032

Muilenburg, L. Y., \& Berge, Z. L. (2005). Student barriers to online learning: A factor analytic study. Distance Education, 26(1), 29-48. https://doi.org/10.1080/01587910500081269

Parnell, D., Widdop, P., Bond, A., \& Wilson, R. (2020). COVID-19, networks and sport. Managing Sport and Leisure. https://doi.org/10.1080/23750472.2020.1750100

Ramchandani, P. (2020). Children and COVID-19. New Scientist, 246(3277): 21. https://doi.org/10.1016/S0262-4079(20)30721-1

Remuzzi, A., \& Remuzzi, G. (2020). COVID-19 and Italy: What next? The Lancet, 395, 12251228. https://doi.org/10.1016/S0140-6736(20)30627-9

Steele, B. (2012). Examination of an online college mathematics course: Correlation between learning styles and student achievement (Doctoral thesis). University of Central Florida.

Tallent-Runnels, M. K., Thomas, J. A., Lan, W. Y., Cooper, S., Ahern, T. C., Shaw, S. M., \& Liu, X. (2006). Teaching courses online: A review of the research. Review of Educational Research, 76(1), 93-135. https://doi.org/10.3102\%2F00346543076001093

The Lancet Public Health. (2020). COVID-19 puts societies to the test. Lancet Public Health, 5(5): e235. https://doi.org/10.1016/S2468-2667(20)30097-9

Van Lancker, W., \& Parolin, Z. (2020). COVID-19, school closures, and child poverty: A social crisis in the making. The Lancet Public Health, 5(5), e243-e244. https://doi.org/10.1016/S2468-2667(20)30084-0

Viner, R. M., Russell, S. J., Croker, H., Packer, J., Ward, J., Stansfield, C., Mytton, O., Bonell, C., \& Booy, R. (2020). School closure and management practices during coronavirus outbreaks including COVID-19: A rapid systematic review. The Lancet Child \& Adolescent Health, 4(5), 397-404. https://doi.org/10.1016/S2352-4642(20)30095-X

Volery, T. \& Lord, D. (2000). Critical success factors in online education. International Journal of Educational Management, 14(5), 216-223. https://doi.org/10.1108/09513540010344731

Zirkle, C. (2001). Access barriers to distance education perceived by in-service and preservice career and technical education majors. https://files.eric.ed.gov/fulltext/ED473768.pdf 